\title{
Tourism for City Branding: A Case of Cirebon
}

\author{
E J Mihardja ${ }^{1}$, Suharyanti ${ }^{2}$, Mirana $\mathrm{H}^{3}$ \\ Communication Science Department, Universitas Bakrie, Jakarta ${ }^{1}$ \\ \{eli.mihardja@bakrie.ac.id $\left.{ }^{1}\right\}$
}

\begin{abstract}
The local government must build a brand for its region in accordance with the potential and positioning of the target area so that it can be more widely known to be considered appropriate for specific purposes, it is deemed appropriate for the place of investment, tourist destination, destination of residence, and organizing activities - events (events) to be perceived as a place with prosperity and high security. In Cirebon Municipal City, one of the potential to serve as a city branding is to integrate its tourism potential. This research is focused on the survey of public perception, tourist attractions, and the tourism industry in Cirebon. Qualitative research by means of in-depth observation and interviews is then conducted to stakeholders and elements of the city government. The results showed that tourism potential could be integrated as city branding of Cirebon with certain conditions, especially the need for maximizing stakeholders' efforts to formulate and guard the potential of this tourism to be built as city branding.
\end{abstract}

Keywords: City Branding, Cirebon Municipal City, Integration Of Tourism

\section{Introduction}

The university can take on the role of building sustainable city branding in an effort to foster regional economic growth [1]. With marketing communication specialized skills, Communication Studies Program University of Bakrie can take on the role of realizing city branding in cities in Indonesia that do not have such a concept. Therefore, this role at the same time is an effort to foster development in all regions of Indonesia.

City branding does not only shape the mindset of the outsiders but also the local people themselves. If successful, the outside community will have more interest in the region or region so as to promote its tourism sector. The first thing that will appear in the minds of tourists is the brand and the impression given by the area so that the area does not have to try too hard to explain itself. For the success of a city branding campaign, local people are forced to maintain and improve their performance to maintain the brand. Thus, the mindset and mindset of the local community are moving toward positivity, slowly, like the spirit of work and cultured life that is certainly appropriate from their city branding.

Cirebon is one of the areas in West Java that has a lot of uniqueness and attraction to be developed into cultural and religious tourism destinations. Formerly Cirebon had been a trade route from various nations that came to transit in Cirebon harbor, so had gradual acculturation with the natives of Cirebon. This adds to the repertoire of cultural diversity-owned by the people of Cirebon. The existence of royal palaces named the Kasepuhan, Kanoman and 
Kacirebon, provide cultural alchemy of local and Hindu-Buddhist. With a history of the entry and development of Islam in Cirebon, the area has the potential to be developed into a cultural and religious tourism hotspot.

Thus, this study was conducted to find out the perception of the community as an internal stakeholder to the potential and development of tourism as an effort to form city branding of Cirebon Municipal City, to map the strategy of city branding of Cirebon Municipal City, and to arrange the development of local tourism potential as an effort to form city branding of Cirebon Municipal City. This research is focused on the survey of public perception, tourist attractions, and the tourism industry in Cirebon Municipal City. Qualitative research by way of observation and in-depth interviews is then done to the stakeholders and elements of the city government. It is hoped that this review provides policy recommendations for local governments on city branding strategies, develops reviews on the application of branding strategies in practical aspects, and develops a study of marketing and tourism communications.

\section{Method}

In this study, interviews with internal and external stakeholders in relation to the management of Cirebon Municipal City tourism were conducted directly face to face. Similarly, observation of the research subject was conducted directly. The selection of respondents for the survey was done by setting the sampling frame by quota. It is known that the number of tourists to the city of Cirebon during 2016 amounted to 6,831 people [2], resulting in an average of 19 tourists a day. This survey was conducted for two days so that the required sampling is 38 people. Furthermore, respondents were caught by convenience sampling [3], which is by targeting the tourists who are easy and willing to fill in the questionnaire.

Selection of informants for qualitative data was done by using purposive sampling technique using the snowball method. The snowball method is a way in which the researcher will select one key informant as the starting point of their research and for the next informant will be based on the recommendation of the first informant, and similarly for subsequent informants. In-depth interviews were conducted continuously from December 2017 to February 2018.

Another informant was found in the open discussion about city branding of Cirebon Municipal City on February 9, 2018. This open discussion was conducted to find out the theme, logo, and nickname of city branding of Cirebon Municipal City that the participants wished for. Participants were also asked to write down the tourism potentials in Cirebon Municipal City to be a city branding. After that, an open discussion of each proposed proposal was proceeded with. The result was recapitulated and included in the analysis as the idea of the tourism industry actors as well as stakeholders against the formation of city branding for Cirebon Municipality.

\section{Results and discussion}

Tourism is defined by [4] About Tourism Chapter I Article 1; it is stated that the tour is a travel activity undertaken by a person or group of persons by visiting a certain place for recreational purposes, personal development or studying the uniqueness of a tourist attraction visited in the interim period. 
Based on the above explanation, the tour basically contains four elements, namely: (1) travel activities; (2) be voluntary; (3) is temporary; (4) the journey is wholly or partially aimed at enjoying tourist objects and attractions. Meanwhile, the definition of a tourist attraction according to Law no. 10 Year 2009 is all that has uniqueness, beauty, and value in the form of diversity of natural wealth, culture and man-made products that become the target or purpose of a tourist visit.

Cirebon has great attraction and tourism potential. Tourism potential is defined as the ability in an area that may be utilized for development, including nature and human as well as the work of man himself [5]. The attraction and potential of this tour need to be developed further.

Tourism as a city branding has been described among others from [6]-[8]. Murfianti explained the effort to build city branding through Solo Batik Carnival. As a cultural event, SBC not only acts as an identity but can be aligned with fashion festivals around the world such as Mardi Grass in New Orleans or Pasadena in California. Ardiansah [7] concluded from the results of his research that the efforts of Kediri government in communicating the development of Pare city brand are done through tourism activities. Jannah et.al [8] found that city branding has an influence on city image and visiting decisions.

The city of Cirebon lies in a strategic location and has become a transport movement node between West Java and Central Java. Being located on the coastal area makes Cirebon Municipal City have a larger terrain area than the hills. The total city of Cirebon is $37.54 \mathrm{~km} 2$ with the dominant use of land for housing (32\%) and agricultural land (38\%).

By the end of 2014, the city of Cirebon had a population of 384,000, up from 300,434 in 2012. The city's per capita GDP per share in 2012 was Rp43.65 million (at current prices) or Rp19.78 million (according to 2000 constant prices). According to BPS Kota Cirebon, in real terms, the purchasing power of the city's population in 2012 grew 5.2\% compared to 2011 . This growth has been observed to increase in the last four years [9].

The public and visitor perceptions of tourism potential are positive. This is reflected from the survey results. The results of a survey measuring knowledge, affection, and behavior of respondents about Cirebon Municipal City tourism showed a positive tendency. Respondents know, like and visit tourist attractions in the city of Cirebon. Respondents enjoy a visit to the tourist attractions the city of Cirebon and felt that they were appropriate sites to be used as the city's identity. However, they felt that the management of sites should be improved and more widely promoted. The findings based on a survey of the local community and visitors to this tourist spot are an asset to promote tourism as the city of Cirebon Municipal City's branding.

The development of trade and services sectors can have a double effect on the tourism sector. The number of migrants who visit Cirebon Municipal City to conduct trade or investment activities increases every year. This can be a positive effect on the tourism sector. The migrants at once can become tourists and/or media promotion of tourist objects in the city of Cirebon. The tourism sector of Cirebon Municipal City has a high potential to be developed and optimized for its role for the economy of Cirebon Municipal City. The development of trade and services sector that is the mainstay for the economy of Cirebon Municipal City currently gives a double effect for the tourism sector. Judging from the number of tourists who come to the city of Cirebon, both with the main reason for travel and business, it is experiencing an upward trend every year.

This is related to the identification of problems in tourism as contained in the document RPJMD West Java. The main issues are (1) not having a comprehensive and competitive tourism and package icon; (2) the management of tourism destinations is still partial and multi-stakeholders (as per Law 10/2013); (3) inadequate supporting facilities for tourism; (4) 
not to institutionalize tourism awareness either to local communities, tourism and tourism actors [9]. Therefore, the development of Tourism Industry of West Java is covered in strategic issues. This strategic issue is a problem related to the phenomenon or has not been resolved in the previous five years and has a long-term impact on the sustainability of development implementation, so it needs to be gradually overcome.

The development of local tourism potential as an effort to form city branding of Cirebon Municipal City requires siding from various parties as stakeholders. As for the tourism potential of the city of Cirebon, city branding is recommended and tourism establishment can also be enhanced by the presence of specific city branding. However, this potential can be implemented if the identification and accommodation of various interests of stakeholders have been mapped and synergized within an integrated strategy. Therefore, it is necessary for opinion leaders to jointly realize the integrated strategy, considering that city branding is an identity that must primarily come from within.

Based on the mapping of city branding strategy, Cirebon also has the potential of cultural, religious, culinary, maritime, services and commerce. Cirebon Municipal City can fulfill the development of thematic development of WKPP III, which include the batik and rattan industry, and local processed food processing industry; preserving the palace, historical tourism and developing ecotourism; as well as developing the metropolitan Cirebon Raya and BIJB and Aerocity Kertajati Area. Furthermore is the need for integration amongst stakeholders in the development town of Cirebon. However, the mapping of the city branding strategy of Cirebon Municipal City which was formed by the government lacks resonance in the community. This happens because of various causes, especially from the conflict of interest from various stakeholders who are development stakeholders in Cirebon Municipality.

\section{Recommendation}

This study can be a reference for the future regarding the establishment of city branding studies in the study field of policy and government strategy. To study the marketing communication, this study could also be developed at an advanced stage in regard to the process of competitive analysis, blueprint; and implementation together with the assessment of the visual communications field and science of government.

This study is also a reflection of real conditions in the Municipal City of Cirebon in an effort to form city branding and also a reflection on tourism. Furthermore, the recommendation is limited to a mapping survey of perception and expectation about a region either from the local community itself or outside parties related to the area. Therefore, there is an opportunity for relevant parties in the fields of the tourism industry, academics, and government institutions to develop this study at the level of implementation in practical aspects.

Acknowledgments. This research was conducted with the internal research financial aid scheme from Research and Development Institute of Bakrie University in the budget year 2017.

\section{References}

[1] R. H. Magnadi and F. Indriani, "Peran Perguruan Tinggi dalam Membangun 'City Branding' yang Berkelanjutan: Sebuah Upaya untuk Mendorong Pertumbuhan 
Perekonomian Daerah," in Prosiding SNaPP: Sosial, Ekonomi dan Humaniora, 2011, pp. 281-290.

[2] F. Nurfalah, "Cirebon Society's Perception about Kasepuhan Palace in Creating Kasepuhan Palace to International Destination," in Proceedings of the 2nd International Conference on Social and Political Development (ICOSOP 2017), 2018, vol. 136, no. Icosop 2017, pp. 242-248.

[3] R. Kriyantono, Teknik praktis riset komunikasi. Jakarta: Kencana, 2006.

[4] Presiden Republik Indonesia, Law of The Republic of Indonesia No. 10 Year 2009 Concerning Tourism. 2009.

[5] Sujali, Geografi Pariwisata dan Kepariwisataan. Yogyakarta: Fakultas Geografi UGM, 1989.

[6] F. Murfianti, "Membangun 'City Branding' melalui Solo Batik Carnival," Acintya J. Penelit. Seni Budaya, vol. 2, no. 1, pp. 13-21, 2010.

[7] D. Ardiansah, "Kampung bahasa sebagai 'City Branding' kota Pare Kediri: Studi kualitatif komunikasi Pemerintah Kabupaten Kediri," UIN Sunan Ampel Surabaya, 2014.

[8] B. Jannah, Z. Arifin, and A. Kusumawati, "Pengaruh City Branding dan City Image terhadap keputusan berkunjung wisatawan ke Banyuwangi," J. Adm. Bisnis, vol. 17, no. 1, pp. 1-17, 2014.

[9] P. J. Barat, "RPJMD West Java Province Year 2013 - 2018," Website Resmi $\begin{array}{llll}\text { Pemerintah Jawa } & \text { Barat. }\end{array}$ http://www.jabarprov.go.id/index.php/pages/id/795. 